\title{
Analiza stanu odżywienia mężczyzn chorych na raka jelita grubego
}

\author{
Agata Lewandowska ${ }^{1}$, Andrzej Deptała ${ }^{2,3}$, Aleksandra Saniewska-Kilim', \\ Łukasz Błoch ${ }^{1}$, Marcin Kasprzyk ${ }^{4}$
}

Wstęp. Dynamiczna ocena stanu odżywiania pacjentów z nowotworem jelita grubego. Ocenę stanu odżywienia badanej grupy $(n=60)$ dokonano poprzez analizę parametrów antropometrycznych i biochemicznych.

Materiał i metody. Selekcja do badania nastąpiła poprzez dobór celowy chorych z bazy danych zawierającej osoby leczone w Klinice Onkologii i Hematologii Centralnego Szpitala Klinicznego MSWiA w Warszawie. Kryteria włączenia do badania stanowiły: dobrowolna i świadoma zgoda pacjenta na uczestniczenie w badaniu, wiek od 18 do 70 lat, rozpoznany i leczony rak jelita grubego. W celu łatwiejszej oceny grupę badaną (B) podzielono na dwie podgrupy, które oznaczono literami BN i BO. Grupę BN stanowili mężczyźni, których wyniki beztłuszczowej masy ciała, określone za pomocą bioimpedancji elektrycznej (BIA) w dniu zakwalifikowania do badania, były w zakresie normy odpowiedniej do wieku i płci, zaś grupa BO składała się z mężczyzn, których ilość beztłuszczowej masy ciała okazała się obniżona w porównaniu do wartości uznanych za normę. Dane demograficzne oraz wyniki badań (stężenie białka całkowitego, bezwzględna liczba limfocytów) uzyskano z historii chorób, natomiast pomiary antropometryczne i ocenę ankietową przeprowadzono za pomocą specjalnie opracowanego do tego celu kwestionariusza oceniającego stan odżywienia pacjenta. Aby uwzględnić z jak największą dokładnością stan odżywienia, kwestionariusz zawierał również autorski zestaw pytań. Pytania te dotyczyły chorób towarzyszących (takich jak: cukrzyca, choroba wrzodowa żołądka i dwunastnicy), a także objawów, które mogą sugerować zaburzenia odżywianie (utrata apetytu, nudności, wymioty, zmiana smaku, biegunka).

Wyniki. Podgrupa BN — niedożywienie w stopniu ciężkim rozpoznano u $8 \%$ chorych, umiarkowanym — u 22\%, lekkim - u 42\%, prawidłowy stan odżywienia rozpoznano u 28\% mężczyzn. Podgrupa BO — niedożywienie w stopniu ciężkim rozpoznawano u 18\% chorych, umiarkowanym - u 52\%, lekkim - u 16\%, prawidłowy stan odżywienia rozpoznano u 14\% mężczyzn. Należy podkreślić, iż w badaniu wykazano istotność statystyczną ( $p>0,05)$ pomiędzy średnim czasem trwania choroby a stopniem niedożywienia w grupie BO. Im dłuższy był czas choroby, tym bardziej w grupie BO odsetek pacjentów był wyższy ze stopniem niedożywienia ciężkim i umiarkowanym.

Wnioski. 1. Zbadani chorzy na RJG stanowili grupę w znacznej mierze niedożywioną (91\%) i tym samym wysoce zagrożoną rozwojem zespołu wyniszczenia nowotworowego. 2. Z uwagi na wykazaną statystyczną zależność pomiędzy dłuższym czasem trwania choroby nowotworowej a pogorszeniem stanu odżywienia należałoby uzupełnić algorytm terapeutyczny dla chorych na RJG o dynamiczną ocenę stanu odżywienia. 3. Ocena stanu odżywienia chorych na nowotwór jelita grubego w oparciu o pojedynczy wskaźnik BMI okazała się niemiarodajna. Dla właściwej oceny stanu odżywienia chorych na nowotwór jelita grubego należy stosować kompleksowy zestaw parametrów, takich jak aktualny i zwyczajowy BMI, procentowy ubytek masy ciała wraz ze szczegółowym procentowym składem masy ciała i parametrami biochemicznymi krwi.

${ }^{1}$ Zakład Profilaktyki Onkologicznej, Wydział Nauki o Zdrowiu, Warszawski Uniwersytet Medyczny — doktorant

${ }^{2}$ Zakład Profilaktyki Onkologicznej, Wydział Nauki o Zdrowiu, Warszawski Uniwersytet Medyczny

${ }^{3}$ Klinika Onkologii i Hematologii, Centralny Szpital Kliniczny MSWiA w Warszawie

${ }^{4}$ Główny Inspektorat Sanitarny 


\section{Analysis of nutritional status in male patients suffering from colorectal cancer}

Introduction. The purpose of this study was to investigate dynamic nutritional status in male patients suffering from colorectal cancer. The assessments were based on anthropometric and biochemical parameters of patients $(n=60)$. Material and methods. The selection of patients for the study was performed by purposive sampling of database of patients treated in the Department of Oncology and Hematology, Central Clinical Hospital of the Polish Ministry of Interior in Warsaw. The selection criteria were: voluntary and informed consent to participate in this study, age between 18 and 70, diagnosed and treated colorectal cancer. The total group of patients (B) was divided into two subgroups, signed BN and BO. BN subgroup included patients whose fat-free mass index, measured by the use of bioelectrical impedance analysis (BIA), where within the normal limits for their age and sex on the first day of the study. BO subgroup included patients with fat-free mass index below standard. Demographic data and tests results (total protein, total white blood cells count) were taken from medical notes. For anthropometric and survey research assessment the questionnaire - worked out specially to assess patients' nutrition status - was sent out. In order to make the measurements of nutrition status as precise as possible, the questionnaire contained an original set of questions, inquiring about concomitant diseases (like: diabetes, peptic ulcer diseases), and symptoms, which might disturb nutrition process (loss of appetite, nausea, vomiting, changed sense of taste, diarrhea).

Results. Subgroup BN - undernourishment in hardest degree was assessed in $8 \%$ of patients, in moderate degree $-22 \%$, in light degree $-42 \%$; while normal nutrition status was recognized in $28 \%$ of patients. Subgroup BO - undernourishment in hardest degree was recognized in $18 \%$ of patients, in moderate degree $-52 \%$, in light degree $16 \%$; while normal nutrition status was recognized in $14 \%$ of patients. It should be stressed that relation between medium duration of disease and undernourishment degree was statistically significant $(p>0.05)$ in BO subgroup. Longer medium duration correlated with the higher percentage of patients with hardest and moderate degree of undernourishment.

Conclusions. 1. Most patients suffering from colorectal cancer who participated in our study were undernourished (91\%) and had therefore high risk of developing cachexia. 2. Due to statistically significant relations between the medium duration of the disease and the degree of undernourishment, the therapeutic algorithm for colorectal cancer should be supplemented with a dynamic assessment of nutrition status. 3. Our research indicates, that the analysis of the nutrition status based on one index - BMI — only is unreliable. Comprehensive assessment requires extensive set of parameters, like: valid and usual BMI, percentage loss of body mass, detailed percentage composition of body mass and blood biochemical parameters.

NOWOTWORY Journal of Oncology 2013; 63, 4: 299-304

Słowa kluczowe: rak jelita grubego, stan odżywienia, niedożywienie, BMI

Key words: colorectal cancer, nutritional status, malnutrition, BMI

\section{Wstęp}

Rak jelita grubego (RJG) jest pierwszym co do częstości występowania nowotworem zarówno u kobiet, jaki u mężczyzn w Europie, zaś w Polsce - na miejscu drugim [1, 2].

Z danych Krajowego Rejestru Nowotworów co roku odnotowuje się ok. 14600 nowych przypadków chorych rocznie, zaś ponad 10400 chorych na ten typ nowotworu umiera. Jednym z głównych czynników zwiększających ryzyko zachorowania na sporadycznego RJG jest niewłaściwy sposób odżywiania, który polega na spożywaniu w nadmiarze produktów wysoko przetworzonych i bogatych w tłuszcz zwierzęcy, a ubogich w warzywa i owoce. $Z$ drugiej strony pacjenci z rozpoznanym i leczonym rakiem jelita grubego są zagrożeni ryzykiem wystąpienia niedożywienia. Niedożywienie może wynikać zarówno z toczącego się procesu chorobowego, jak i z wpływu operacji i/lub chemioterapii [3, 4]. Profesjonalna ingerencja wnawyki żywieniowe chorych na raka jelita grubego mogłaby przynieść wymierne korzyści pacjentom w zakresie poprawy jakości życia, a być może również spowodować wydłużenie przeżycia całkowitego [4-6]. Jednakże aby zmienić styl życia i udowodnić ww. korzyści, najpierw należy przeanalizować stan odżywienia chorych na RJG, zwłaszcza mężczyzn, którzy częściej zapadają na raka, a także o wiele trudniej poddają się wszelkim procedurom medycznym niż kobiety [7-9]. Dlatego celem badania była ocena stanu odżywiania mężczyzn chorych na raka jelita grubego.

\section{Materiał i metody}

Selekcja do badania nastąpiła poprzez dobór celowy chorych z bazy danych zawierającej osoby leczone w Klinice Onkologii i Hematologii Centralnego Szpitala Klinicznego MSWiA wWarszawie. Kryteria włączenia do badania stanowiły: dobrowolna i świadoma zgoda pacjenta na uczestniczenie w badaniu, wiek od 18 do 70 lat, rozpoznany i leczony rak 
Tabela I. Prawidłowe wartości składu ciała w zależności od wieku i płci [9]

\begin{tabular}{lcccccc}
\hline \multirow{2}{*}{ Wiek } & \multicolumn{2}{c}{ Beztłuszczowa masa ciała - BMC (\%) } & \multicolumn{2}{c}{ Tłuszczowa masa ciała - TMC (\%) } & \multicolumn{2}{c}{ Udział wody w ciele - UWC (\%) } \\
\cline { 2 - 6 } & Mężczyźni & Kobiety & Mężczyźni & Kobiety & Mężczyźni & Kobiety \\
\hline$<30$ & $80-85$ & $78-80$ & $15-18$ & $16-20$ & 65 & 62 \\
$30-50$ & $78-80$ & $76-78$ & $18-20$ & $22-26$ & 60 & 58 \\
$>50$ & $75-80$ & $70-75$ & $20-22$ & $28-36$ & 58 & 55 \\
\hline
\end{tabular}

jelita grubego (leczenie chemioterapeutyczne po operacji resekcji częściowej lub całkowitej jelita grubego). Kryteria wyłączenia z badania były następujące: brak zgody pacjenta lub niespełnienie któregokolwiek z powyższych kryteriów włączenia. Na przeprowadzenie badań uzyskano zgodę Komisji Bioetycznej Warszawskiego Uniwersytetu Medycznego nr KB/122/2010 z dnia 25 maja 2010 roku.

Świadomą zgodę na badanie podpisało 60 mężczyzn. W celu łatwiejszej oceny grupę badaną (B) podzielono na dwie podgrupy, które oznaczono literami BN i BO. Całą grupę badaną stanowili pacjenci, którzy byli po resekcji całkowitej lub częściowej jelita grubego oraz otrzymywali leczenie chemioterapeutyczne adiuwantowe.

Grupę BN stanowili mężczyźni, których wyniki beztłuszczowej masy ciała, określone za pomocą bioimpedancji elektrycznej (BIA) w dniu zakwalifikowania do badania, były w zakresie normy odpowiedniej do wieku i płci, zaś grupa BO składała się z mężczyzn, których ilość beztłuszczowej masy ciała okazała się obniżona w porównaniu do wartości uznanych za normę.

W tabeli I podano prawidłowe wartości składu ciała w zależności od wieku i płci.

Dane demograficzne oraz wyniki badań (stężenie białka całkowitego, bezwzględna liczba limfocytów) uzyskano z historii chorób, natomiast pomiary antropometryczne i ocenę ankietową przeprowadzono za pomocą specjalnie opracowanego do tego celu kwestionariusza oceniającego stan odżywienia pacjenta.

W tabeli ll podano zasady klasyfikacji stanu odżywienia i przypisane im zakresy norm wskaźnika masy ciała (BMI, body mass index) zaproponowane przez Światową Organizację Zdrowia (WHO).

Aby uwzględnić z jak największą dokładnością stan odżywienia, kwestionariusz zawierał również autorski zestaw pytań. Pytania te dotyczyły chorób towarzyszących (takich jak: cukrzyca, choroba wrzodowa żołądka i dwunastnicy), a także objawów, które mogą zaburzać odżywianie (utrata apetytu, nudności, wymioty, zmiana smaku, biegunka) [11-13]. Po wypełnieniu kwestionariusza każdy badany pacjent mógł uzyskać od 18 do 90 punktów. Liczba uzyskanych punktów określała stan odżywienia danego pacjenta. Przyjęto wg Nutritional Risk Screening (NRS 2002) następujące przedziały punktowe w celu oceny stanu odżywienia pacjentów [9]: — ciężkie niedożywienie - 71-90 punktów;
Tabela II. Klasyfikacja stanu odżywienia w zależności od BMI według WHO [10]

\begin{tabular}{lc}
\hline Klasyfikacja wg WHO & BMI $\left[\mathrm{kg} / \mathrm{m}^{2}\right]$ \\
\hline Niedowaga & $<18,50$ \\
Ciężkie niedożywienie & $<16,00$ \\
Umiarkowane niedożywienie & $16,00-16,99$ \\
Lekkie niedożywienie & $17,00-18,49$ \\
Norma & $\mathbf{1 8 , 5 0 - 2 4 , 9 9}$ \\
Nadwaga & $\geq 25,00$ \\
Znaczna nadwaga & $25,00-29,99$ \\
Otyłość & $\geq 30,00$ \\
Otyłość $\left.\right|^{\circ}$ & $30,00-34,99$ \\
Otyłość II & $35,00-39,99$ \\
Otyłość III & $\geq 40,00$ \\
\hline
\end{tabular}

- umiarkowane niedożywienie - 61-70 punktów;

- lekkie niedożywienie - 40-60 punktów;

— prawidłowy stan odżywienia - 18-39 punktów.

Zarówno kwestionariusz, jak i parametry oceniające stan odżywienia oraz sposób ich obliczenia zamieszczono w odpowiednich tabelach i rycinach na końcu pracy. Obliczeń statystycznych dokonano, używając programów Microsoft Office 2003 oraz Statistica 6.0.

\section{Wyniki}

Średnia wieku w grupie badanej (B) wyniosła 59,15 roku w podgrupach BN (mężczyźni z prawidłową beztłuszczową masą ciała) i BO (mężczyźni z obniżoną beztłuszczową masą ciała). Średnie wartości wieku nie różniły się istotnie i wynosiły odpowiednio: 61,1 roku i 57,2 roku. Średni czas trwania choroby (od momentu rozpoznania RJG) w grupie B wyniósł 16,2 miesiąca, w podgrupie $\mathrm{BN}-12,9$ miesiąca, a w podgrupie $B O-17,8$ miesiąca. Analiza średnich wartości BMI ${ }^{\mathrm{A}}$ wykazała, że pacjenci z grup $\mathrm{B}, \mathrm{BN}$ i BO uzyskali wyniki mieszczące się w granicy uznawanej za normę dla tego wskaźnika (tab. II). Po obliczeniu średnich wartości $\mathrm{BMI}^{\mathrm{Z}}$ okazało się, że w grupie B wyniosła ona aż 32,2 (kg/m²). W grupie B osoby bez nadwagi i otyłości w przeszłości stanowiły tylko 22\%. Najniższą średnią wartość BMI ${ }^{\mathrm{Z}}$ odnotowano w BN - 27,4 (kg/m²). W grupie BO wyniki otrzymane po obliczeniu wskaźnika BMI ${ }^{z}$ wykazały, że $48 \%$ badanych z tej grupy w przeszłości charakteryzowało się nadwagą, 
Tabela III. Parametry pomiarów antropometrycznych w badanej grupie mężczyzn

\begin{tabular}{lccc}
\hline Podział & Średnie wartości BMI ${ }^{\mathrm{A}}\left[\mathrm{kg} / \mathrm{m}^{2}\right]$ & Średnie wartości BMI ${ }^{\mathrm{Z}}\left[\mathrm{kg} / \mathrm{m}^{2}\right]$ & $\begin{array}{c}\text { Średni ubytek masy ciała w ciągu } \\
\text { ostatnich } 6 \text { miesięcy (\%) }\end{array}$ \\
\hline B & 23,5 & 32,2 & 22,6 \\
BN & 22,9 & 27,4 & 13,2 \\
BO & 22,3 & 30,0 & 21,2 \\
\hline
\end{tabular}

$\mathrm{BMI}^{\mathrm{A}}$ - BMI obliczone na podstawie aktualnej masy ciała; BMI $\mathrm{Z}$ - BMI obliczone na podstawie zwyczajowej masy ciała, tzn. uzyskanej z wywiadów

a co bardziej niepokojące, aż 30\% z nich charakteryzowało się otyłością lo.

Po dokonaniu porównania średnich wartości ubytku masy ciała odnotowano, iż grupa B charakteryzowała się najwyższą średnią wartością ubytku masy ciała $(22,6 \%)$, zaś najniższy wynik uzyskała grupa BN - 13,2\%. Pozostałe wyniki badań antropometrycznych ukazuje tabela III.

Pomiar metodą BIA dostarczył informacji o procentowym składzie masy ciała: beztłuszczowej (BMC), tłuszczowej (TMC) i udziale wody (UWC). Średnie tych parametrów zostały przedstawione $w$ tabeli IV.

Uzyskane dane zostały porównanez normami podanych w tabeli I. Stwierdzono, że podgrupa BN odznaczała się najbardziej zbliżonymi do norm wynikami w zakresie BMC, odwrotna zależność charakteryzowała grupę BO.

Analiza parametrów biochemicznych przeprowadzona w zakresie ilości białka całkowitego i bezwzględnej liczby limfocytów wykazała, że większość mężczyzn z grupy badanej miała wyniki poniżej normy. Stężenie białka całkowitego w grupie B było poniżej normy u $67 \%$ chorych. W podgrupach BN i BO uzyskane wyniki nie różniły się od tych z grupy B. Bezwzględna liczba limfocytów była najniższa w grupie BO — aż 70\% mężczyzn uzyskało wynik poniżej normy. W grupie BN odsetek chorych z obniżoną liczbą limfocytów wyniósł 62,3\%.

Analizując dolegliwości, które mogły stanowić przeszkodę w spożywaniu posiłków stwierdzono, że w grupie B blisko 3/4 osób (70\%) zgłosiło problem nawracających nudności. Drugą co do częstotliwości występowania w tej grupie dolegliwością była zmiana smaku. Wymioty i biegunki były zgłaszane znacznie rzadziej (wymioty - 32\%; biegunki - 25\%). Większość (95\%) badanych mężczyzn w grupie B stwierdziła, że oprócz wyżej wymienionych dolegliwości odczuwali również zmniejszenie chęci jedzenia (spadek apetytu).

Po dokonaniu analizy badań antropometrycznych (BMI ${ }^{\mathrm{A}}$, $\mathrm{BMI}^{\mathrm{z}}$, procentowy ubytek masy ciała, procentowy skład masy ciała - BMC, TMC, UWC), badań biochemicznych oraz autorskiego arkusza pytań pomocniczych wykazano, że w grupie B ciężkie niedożywienie dotyczy $25 \%$ przypadków, umiarkowane - 43\%, a lekkie - 23\%. Tylko u 9\% osób stwierdzono prawidłowy stan odżywienia. Poziom odżywienia w podgrupach przedstawia rycina 1.
Tabela IV. Parametry oceny składu ciała

\begin{tabular}{lccc}
\hline $\begin{array}{l}\text { Grupa } \\
\text { badana }\end{array}$ & $\begin{array}{c}\text { Średnia } \\
\text { BMC (\%) }\end{array}$ & $\begin{array}{c}\text { Średnia } \\
\text { TMC (\%) }\end{array}$ & $\begin{array}{c}\text { Średnia } \\
\text { UWC (\%) }\end{array}$ \\
\hline B & 53,8 & 39,5 & 43,2 \\
BN & 66,4 & 23,9 & 47,4 \\
BO & 51,5 & 37,2 & 39,1 \\
\hline
\end{tabular}

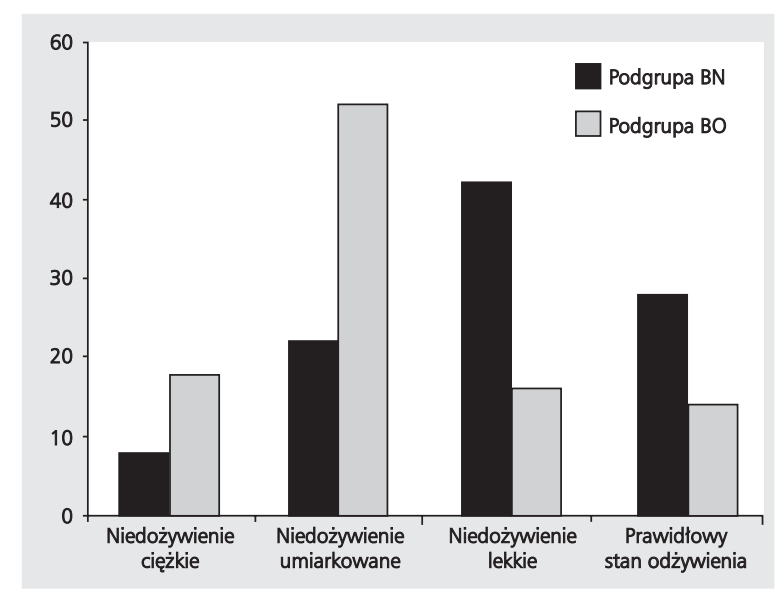

Rycina 1. Poziom odżywienia w podgrupach BN i BO

Po podzieleniu grupy B na podgrupy wyniki wypadły następująco:

- podgrupa BN - niedożywienie w stopniu ciężkim u 8\% chorych, umiarkowanym - u 22\%, lekkim — u 42\%, prawidłowy stan odżywienia rozpoznano u $28 \%$ mężczyzn;

- podgrupa BO - niedożywienie w stopniu ciężkim u 18\% chorych, umiarkowanym - u 52\%, lekkim — u 16\%, prawidłowy stan odżywienia rozpoznano u 14\% mężczyzn. Należy podkreślić, że w pracy wykazano istotność statystyczną ( $p>0,05)$ między średnim czasem trwania choroby a stopniem niedożywienia w grupie BO. Im dłuższy był czas choroby, tym w grupie BO wyższy był odsetek pacjentów ze stopniem niedożywienia ciężkim i umiarkowanym.

\section{Dyskusja}

Chorzy na raka jelita grubego, którzy zostali zakwalifikowani do badania, przebyli leczenie chirurgiczne (resekcję odpowiedniej części jelita grubego) i zostali poddani che- 
mioterapii adiuwantowej. Sama choroba nowotworowa, zwłaszcza jej postać zaawansowana, wiąże się bezpośrednio z dużym ryzykiem wystąpienia niedożywienia. Dodatkowym czynnikiem sprzyjającym niedożywieniu jest leczenie onkologiczne oraz sama choroba nowotworowa. Niedożywienie może stanowić znaczą przeszkodę podczas leczenia onkologicznego. Szybki ubytek masy ciała (5\% aktualnej masy ciała w ciągu 6 mies.) stanowi również ważny element prognostycznie negatywny. Dlatego należy jak najczęściej monitorować stan odżywienia i w porę wprowadzać zmiany zarówno ilościowe, jak i jakościowe w żywieniu pacjentów z nowotworami jelita grubego. W niektórych przypadkach należy rozważyć wprowadzenie żywienia parenteralnego przed rozpoczęciem chemioterapii, aby uniknąć rozwoju zespołu wyniszczenia nowotworowego, który w krótkim okresie może prowadzić do śmierci [11].

Po przeprowadzeniu oceny stanu odżywienia wśród mężczyzn chorych na RJG w oparciu o kwestionariusz oceny odżywienia stwierdzono, że tylko $9 \%$ z nich jest prawidłowo odżywionych po średnio 12 miesiącach od rozpoznania i rozpoczęcia leczenia. Bardzo istotnym czynnikiem w ocenie stanu odżywienia, na który należy zwrócić szczególną uwagę, jest procentowy ubytek masy ciała w przeciągu ostatnich 6 miesięcy. Jużutrata 5\% wyjściowej masy ciała w chorobie nowotworowej stanowi bardzo niepokojący wskaźnik [11, 12]. W przeprowadzonym badaniu średni ubytek masy ciała w grupie badanej B stanowił aż 22\% wyjściowej masy ciała. Ten znaczący stopień ubytku powinien sugerować lekarzom, pielęgniarkom, dietetykom i personelowi medycznemu, że nasilają się procesy kataboliczne, które są skutkiem zarówno choroby nowotworowej, jak i leczenia onkologicznego, a rozwój pełnego zespołu wyniszczenia nowotworowego ze wszystkimi negatywnymi skutkami jest tylko kwestią czasu $[6,7]$. W takiej sytuacji należy niezwłocznie poddać tego typu chorych kompleksowej ocenie stanu odżywienia, na którą powinny składać się zarówno wyniki badania antropometrycznego, jak i wyniki badań biochemicznych krwi. Ponadto należy przeprowadzić dokładne badanie podmiotowe, które musi uwzględnić choroby towarzyszące oraz dolegliwości utrudniające spożywanie pokarmów, takie jak: wymioty, nudności, brak apetytu czy smaku [11-13]. W wywiadach należy także uwzględnić czas hospitalizacji, rodzaj diety stosowanej w szpitalu i ograniczenia dietetyczne, które sam pacjent często sobie narzuca, być może sugerując się niesprawdzonymi informacjami z niepewnych źródeł [8].

Częstym zjawiskiem w szpitalach jest fakt oceny stanu odżywienia tylko na podstawie jednego wskaźnika. Takie podejście wydaje się być niewłaściwe. Najłatwiejszym i tym samym powszechnie używanym jest wskaźnik BMI. W badaniu wskaźnik BMI wyliczono na dwa sposoby. Jeden sposób wyliczenia BMI opierał się na pomiarze aktualnej masy ciała i został oznaczony jako $\mathrm{BMI}{ }^{\mathrm{A}}$ - aktualny. W drugim sposobie wyliczenia, nazwanym $\mathrm{BMI}^{\mathrm{Z}}$ - zwyczajowym - w liczni- ku wzoru umieszczono masę ciała, którą podawali chorzy w kwestionariuszu. Paradoksem jest sytuacja, gdy pacjent posiadający w momencie diagnozy choroby nowotworowej znaczą nadwagę lub otyłość, a po kilku miesiącach zazwyczaj intensywnego leczenia (chirurgicznego i chemioterapii) tracący znaczą ilość wyjściowej masy ciała, może zostać sklasyfikowany na podstawie $\mathrm{BMI}^{\mathrm{A}}$ jako prawidłowo odżywiony. W przeprowadzonym badaniu udowodniono, że ocena stanu odżywienia na podstawie tylko tego jednego wskaźnika jest niemiarodajna [8]. Po obliczeniu $\mathrm{BMI}^{\mathrm{Z}}$ okazało się, że większość pacjentów w przeszłości borykała się z nadwaga lub otyłością. Po uwzględnieniu procentowego ubytku wyjściowej masy ciała wyniki wypadły alarmująco. Średnie wartości procentowego ubytku masy ciała w okresie 6 miesięcy w grupie badanej zostały oszacowane na $22,9 \%$, podczas gdy ubytek tylko 5\% wyjściowej masy ciała powinien być alarmem o istnieniu wysokiego tempa katabolizmu. Po przeanalizowaniu wyników procentowego składu ciała zaobserwowano, że w dniu pomiaru w grupie badanej tylko część pacjentów (podgrupa BN) odznaczała się prawidłowym stosunkiem ilości tkanki mięśniowej do ilości tkanki tłuszczowej. Pozostała część pacjentów (podgrupa BO) miała zaburzoną proporcję składu ciała. Najczęstszym zaburzeniem w podgrupie BO był zbyt wysoki udział tkanki tłuszczowej, a zbyt niski procent tkanki mięśniowej. Szybka i niezamierzona utrata masy ciała jest wartością prognostyczną dla pacjentów z chorobami nowotworowymi $[11,12]$.

W badaniu autorzy dowiedli również, że im dłuższy średni czas trwania choroby, tym gorszy stan odżywienia pacjentów. Zależność ta wypadła istotnie statystycznie. Wynik należy uzasadniać tym, że im dłuższy czas pacjent choruje, tym dłuższe jest stosowanie leków przeciwnowotworowych i więcej razy dochodzi do hospitalizacji, co ma bezpośrednie przełożenie na chęć spożywania pokarmów, możliwość absorpcji składników odżywczych, a także nasilenie procesów katabolicznych w organizmie [13].

Reasumując, po dokonaniu kompleksowej oceny stanu odżywienia mężczyzn chorych na raka jelita grubego stwierdzono, że większość badanych osób była niedożywiona w stopniu ciężkim lub umiarkowanym.

\section{Wnioski}

1. Zbadani chorzy na RJG stanowili grupę w znacznej mierze niedożywioną (91\%) i tym samym wysoce zagrożoną rozwojem zespołu wyniszczenia nowotworowego.

2. Z uwagi na wykazaną statystyczną zależność pomiędzy dłuższym czasem trwania choroby nowotworowej a pogorszeniem stanu odżywienia należałoby uzupełnić algorytm terapeutyczny dla chorych na RJG o dynamiczną ocenę stanu odżywienia.

3. Ocena stanu odżywienia chorych na nowotwór jelita grubego w oparciu o pojedynczy wskaźnik BMI oka- 
zała się niemiarodajna. Dla właściwej oceny stanu odżywienia chorych na nowotwór jelita grubego należy stosować kompleksowy zestaw parametrów, takich jak aktualny i zwyczajowy BMI, procentowy ubytek masy ciała wraz ze szczegółowym procentowym składem masy ciała i parametrami biochemicznymi krwi.

\section{Mgr dietetyk Agata Lewandowska}

Zakład Profilaktyki Onkologicznej

Warszawski Uniwersytet Medyczny

Szpital Kliniczny MSWiA

ul. Wołoska 137, 02-507 Warszawa

e-mail:agatkowska@tlen.pl

Otrzymano: 4 stycznia $2013 \mathrm{r}$.

Przyjęto do druku: 26 lutego 2013 r.

\section{Piśmiennictwo}

1. Didkowska J, Wojciechowska U, Tarkowski Wi wsp. Nowotwory złośliwe w Polsce w 2000 roku. Centrum Onkologii — Instytut, Warszawa 2006.

2. Frykholm GJ, Glimelius B, Pahlman L. Preoperative or postoperative irradiation in adenocarcinoma of the rectum: final treatment results of a randomized trial and an evaluation of late secondary effects. Dis Colon Rectum 1993; 36: 564-572.

3. Axworthy L, Spiegel J. Retaining Canada's health care system as global public good. Can Med Assoc J 2002; 167: 365-366.

4. Krasuska ME. Rola odżywiania w profilaktyce onkologicznej. Zdr Publ 2006; 116: 267.

5. Kohlmeier L, Simonsen N, Mottus K. Dietary modifiers of carcinogenesis. Environ Health Prospect 1995; 103, suppl. 8: 177-184.

6. Mantovani G, Lizak A, Kałmuk A i wsp. Cachexia and anorexia. Support Care Cancer 2000; 8: 506-509.

7. Tchekmedyian NS, Zahyna D, Halpert C i wsp. Clinical aspects of nutrition in advanced cancer. Oncology 1992; 49 (suppl. 2): 3-7.

8. Lizak A, Kałmuk A, Huras B i wsp. Zespół wyniszczenia nowotworowego — etiopatogeneza w świetle aktualnej wiedzy. Współcz Onkol 2003; 6: 441-447.

9. Kondrup J i wsp. Nutritional risk screening (NRS 2002): a new method based on an analysis of controlled clinical trials. Clin Nutr 2003; 22: 321-336.

10. WHO, http://www.who.int/childgrowth/standards/chts_bfa_boys_p/en/index.html.[10.10.2009].

11. Calman $\mathrm{KC}$ and Fearon $\mathrm{KCH}$. Weight loss and nutritional abnormalities in cancer patients: incidence, severity and significance. W: Clinics in oncology. Saunders, London 1986: 115-126.

12. Agustsson $T$, Ryden $M$, Hoffstedt J i wsp. Mechanism of increased lipolysis in cancer cachexia. Cancer Res 2007; 67: 5531-5537.

13. Bosaeus I, Daneryd P, Svanberg E i wsp. Dietary intake and resting energy expenditure in relation to weight loss in unselected cancer patients. Int J Cancer 2001; 93: 380-383. 